\title{
2,2-Diphenyl-1-picrylhydrazil radical scavenging activity of extracts from roots and leaves of Searsia burchellii
}

\author{
${ }^{1}$ Mpopo, M.S., , ${ }^{1,}$ Pillai, M.K. and ${ }^{2}$ Mekbib, S.B. \\ ${ }^{1}$ Department of Chemistry and Chemical Technology, Faculty of Science and Technology, National \\ University of Lesotho, Roma campus, P.O. Roma 180, Kingdom of Lesotho, Southern Africa \\ ${ }^{2}$ Department of Biology, Faculty of Science and Technology, National University of Lesotho, Roma Campus, \\ P. O. Roma 180, Kingdom of Lesotho, Southern Africa
}

\begin{abstract}
Article history:
Received: 6 October 2020

Received in revised form: 9

November 2020

Accepted: 10 November 2020

Available Online: 21 March

2021
\end{abstract}

Keywords:

Searsia burchellii,

Anacardiaceae,

Extracts from leaves and

roots,

DPPH radical scavenging

assay,

$\mathrm{IC}_{50}$ values.

DOI:

https://doi.org/10.26656/fr.2017.5(2).567

\begin{abstract}
Searsia burchellii finds therapeutic applications in traditional medicine. Methanolic extracts, hexane, chloroform, ethyl acetate and methanol/water fractions of methanolic extracts and water extracts were obtained separately from the roots and leaves of Searsia burchellii by the combination of maceration, hot solvent extraction and solvent-solvent partition techniques. These extracts were evaluated for their antioxidant activity using 2,2diphenyl-1-picrylhydrazil radical scavenging assay (DPPH). The extracts from roots and their fractions showed radical scavenging activity ranging from $6.60 \pm 4.50$ to $63.27 \pm 1.93 \%$ at various concentrations. Similarly, the extracts from leaves and their fractions showed radical scavenging activity ranging from $3.32 \pm 0.95$ to $64.91 \pm 0.15 \%$ at various concentrations. Ascorbic acid served as positive control which showed radical scavenging activity ranging from $53.62 \pm 2.80$ to $60.82 \pm 0.62 \%$ at various concentrations. The $\mathrm{IC}_{50}$ values of these extracts and fractions were found to be $<200$ to $>3000 \mu \mathrm{g} / \mathrm{mL}$. The $\mathrm{IC}_{50}$ value of ascorbic acid was found to be $<200 \mu \mathrm{g} / \mathrm{mL}$. From this study, we concluded that extracts and their fractions from $S$. burchellii showed promising radical scavenging activity.
\end{abstract}

\section{Introduction}

Searsia burchellii belongs to the Anacardiaceae family of the Searsia (Rhus) genus. S. burchellii is widely distributed in South Africa, Lesotho and Namibia (Palmer and Pitman, 1972; Moffett, 1994; Palgrave, 2002). The vernacular names of this plant are Karoo kuni -bush, Karookoeniebos, Motshotlho and Mokhoamphiri (Smith, 1966; Van Wyk and Gericke, 2000; Germishuizen and Meyer, 2003; Moffet, 2007). S. burchellii is an evergreen shrub and grows up to 5 meters in height. S. burchellii has densely populated olive green waxy leaves, grey coloured stem-bark, cream-colored flowers of 4-6 cm long and yields reddish-brown fleshy fruits (Compton, 1976; Van Wyk and Van Wyk, 1997; Van Oudtshroorn and Gericke, 1997; New Winger, 2000; Palgrave, 2002). S. burchellii has been used to treat tuberculosis, respiratory and pulmonary diseases, fever, cold and problems associated with childbirth (Nielsen et al., 2012; Umberto, 2012). Plants from the Searsia genus have been shown to possess antiinflammatory, antimalarial, antimicrobial, antidiarrheal, anticancer, antiviral, hepatoprotective and antioxidant activities (Djakpo and Yao, 2010; Moteetee and Van Wyk, 2011; El-Salam and Mohammed, 2015; Moteetee and Kose, 2017; Mtunzi et al., 2017). However, the species $S$. burchellii, which belongs to the same Searsia genus, has not been explored for its biological and pharmacological activities so far. The aim of the current study was to evaluate the 2,2-diphenyl-1-picrylhydrazil radical scavenging activity of various organic solvents and aqueous extracts from roots and leaves of $S$. burchellii collected from the kingdom of Lesotho and to determine their $\mathrm{IC}_{50}$ values.

\section{Materials and methods}

\subsection{Plant materials}

The roots and leaves of $S$. burchellii were collected in January and March 2020 along the Senqu River at Ha Ramatseliso village in Thaba-Tseka district and on the hills of Maseru district in the Kingdom of Lesotho, Southern Africa. The plant materials were identified by Dr Lerato Seleteng-Kose, Department of Biology, National University of Lesotho, Roma campus, The Kingdom of Lesotho. 


\subsection{Processing of plant materials}

The plant materials were air-dried at room temperature for three weeks at Organic Chemistry Laboratory and then pulverized into powder using a grinding machine (HSIANGTAI, Mode SM-450L, AC220V, 50HZ, MRC Laboratory Equipment). A mass of 1160.83 and $997.17 \mathrm{~g}$ of powdered roots and leaves, respectively were obtained.

\subsection{Preparation of plant extracts and fractions}

A mass of $854.31 \mathrm{~g}$ of powdered leaves was macerated with $3.5 \mathrm{~L}$ of methanol for $72 \mathrm{hrs}$. The resulting solution was filtered off through a Whatman no. 1 filter paper and a methanolic crude leaf extract was obtained. The above procedure was repeated twice and the extract was combined. Finally, the same material was extracted under reflux condition (about $65^{\circ} \mathrm{C}$ ) for $10 \mathrm{hrs}$ and the solution was concentrated. A mass of $244.33 \mathrm{~g}$ of combined methanolic crude leaf extract was obtained. Water extract from the leaves was obtained by boiling $142.86 \mathrm{~g}$ of powder with $300 \mathrm{~mL}$ of distilled water at $80^{\circ}$ $\mathrm{C}$ for $10 \mathrm{hrs}$. A mass of $20.23 \mathrm{~g}$ of water leaf extract was obtained on concentration. Using a similar extraction procedure, a mass of 84.05 and $7.29 \mathrm{~g}$ of methanolic and water extracts, respectively were obtained from 1075.37 and $85.46 \mathrm{~g}$ of root powder. A mass of 5.15 and 85.15 of these methanolic crude extracts from roots and leaves, respectively were kept separately for their radical scavenging activity and other studies.

A mass of $159.179 \mathrm{~g}$ crude methanolic leaf extract was suspended in methanol-water $(1: 1 \mathrm{v} / \mathrm{v})$ and subjected to solvent-solvent partition successively with hexane, chloroform and ethyl acetate. A mass of 18.953, 102.283 and $9.410 \mathrm{~g}$ of hexane, chloroform and ethyl acetate fractions, respectively were obtained. A mass of 22.879 $\mathrm{g}$ of the remaining methanol-water fraction was also obtained on concentration. Similarly, 2.703, 5.164, 15.856 and $46.548 \mathrm{~g}$ of hexane, chloroform, ethyl acetate and methanol-water fraction, respectively were obtained from $78.899 \mathrm{~g}$ crude methanolic root extract.

\subsection{Chemicals used}

AR Grade of hexane, chloroform, ethyl acetate, methanol, tris(hydroxymethyl)aminomethane and 2,2diphenyl-1-picrylhydrazil (DPPH) were all purchased from Sigma-Aldrich. AR Grade of L-ascorbic acid was purchased from Minema Ltd.

2.5 Evaluation of DPPH radical scavenging activity of various extracts and their fractions and determination of their $I C_{50}$ values

DPPH radical scavenging activity of various extracts and fractions from the leaves and roots of $S$. burchellii was determined by methods described in the literature (Mokoroane et al., 2020; Matamane et al., 2020) with slight modifications. Briefly, stock solutions of crude extracts and fractions were prepared separately by dissolving $30 \mathrm{mg}$ in $10 \mathrm{~mL} \mathrm{50 \%} \mathrm{methanol} \mathrm{(v/v).} \mathrm{Further}$ dilutions such as 3000, 2000, 1500, 1000, 800, 500 and $200 \mu \mathrm{g} / \mathrm{mL}$ were prepared from the stock solutions. The solutions without extracts or fractions served as negative controls. A volume of $0.1 \mathrm{~mL}$ of each extract solution was mixed separately with $1.0 \mathrm{~mL}$ of $0.1 \mathrm{mM}$ DPPH solution and $1.0 \mathrm{~mL}$ of $50 \mathrm{mM}$ Tris-HCL buffer $(\mathrm{pH}$ 7.40) solution. The resulting mixture was vortexed and then incubated at room temperature in the dark for 30 min. A stock solution of ascorbic acid $(0.3 \mathrm{~g})$ in $50 \%$ methanol $(\mathrm{v} / \mathrm{v})$ was prepared and serial dilutions were made as previously which served as a positive control. The absorbance of the mixture was measured at $517 \mathrm{~nm}$ using MRM Spectrophotometer (Mode Spectro UV-11, $\mathrm{S} / \mathrm{N}$ : UEB 1704200). The assays were performed in triplicates. The percentage inhibition activity of extracts or fractions was calculated by the formula: $\left[\left(\mathrm{A}_{\text {cont }}-\mathrm{A}_{\text {test }}\right) /\right.$ Acont $) \times 100]$, where $A_{\text {cont }}$ is the absorbance of the negative control and $A_{\text {test }}$ is the absorbance of the extract or fraction or positive control.

The $\mathrm{IC}_{50}$ values of these extracts or fractions were calculated using Microsoft Excel by plotting extract concentration versus percentage inhibition of DPPH radical. Each experiment was carried out in triplicate and the average of the three values was used to calculate the $\mathrm{IC}_{50}$ value for each extract. The $\mathrm{IC}_{50}$ value is defined as the concentration of extract that inhibits the formation of DPPH radical by 50\% (Moyo et al., 2013; Ndhlala et al., 2013). A lower value of $\mathrm{IC}_{50}$ represents higher antioxidant activity and vice versa. Standard deviation was calculated for each concentration from the three values of the experiments.

\subsection{Statistical analysis}

Data analysis was performed using the SPSS 17.0 statistics program by means of a two-way analysis of variance. The differences were considered statistically significant when $\mathrm{p} \leq 0.05$.

\section{Results and discussion}

The methanolic crude extract (E1) was prepared from the roots of $S$. burchellii and four fractions were obtained from this methanolic crude extract viz. hexane fraction (E2), chloroform fraction (E3), ethyl acetate fraction (E4) and methanol-water (E5). Additionally, water extract (E6) was also prepared separately from the root powder. Similarly, methanolic crude extract E7) was 
prepared from the leaves of $S$. burchellii and four fractions were obtained from this methanolic crude extract viz. hexane fraction (E8), chloroform fraction (E9), ethyl acetate fraction (E10) and methanol-water fraction (E11). Additionally, water extract (E12) was also prepared separately from the powdered leaves. All these extracts and fractions were evaluated for their antioxidant activity at various concentrations by DPPH radical scavenging assay and the results are summarised in Table 1. Ascorbic acid served as a positive control.

Extract E1 showed slightly lower scavenging activity than positive control at all concentrations. Fraction E2 exhibited much lower radical scavenging activity at lower concentrations and showed significant radical scavenging activity at higher concentrations at 2000 and $3000 \mu \mathrm{g} / \mathrm{mL}$. Fraction E3 showed lower radical scavenging activity at a lower concentration at $200 \mu \mathrm{g} /$ $\mathrm{mL}$ and showed higher radical scavenging activity at higher concentrations at $500-3000 \mu \mathrm{g} / \mathrm{mL}$. Fractions E4 and E5 exhibited higher radical scavenging activity as compared to the positive control at all concentrations. Extract E6 showed comparable radical scavenging activity as that of positive control at all concentrations. Extract 7 showed lower radical scavenging activity than positive control at all concentrations. Fractions E8 and E9 exhibited much lower radical scavenging activity at all concentrations. Fraction E10 showed a lower radical scavenging activity at $200 \mu \mathrm{g} / \mathrm{mL}$ and showed higher radical scavenging activity at $500-3000 \mu \mathrm{g} / \mathrm{mL}$ compared to the positive control. Fraction E11 showed a lower radical scavenging activity at lower concentrations at $200-500 \mu \mathrm{g} / \mathrm{mL}$ and showed higher radical scavenging activity at higher concentrations at $800-3000 \mu \mathrm{g} / \mathrm{mL}$. Extract E12 showed lower radical scavenging activity at all concentrations relative to the positive control (Table 1). The DPPH radical scavenging activity of various extracts from roots and leaves of S.burchellii were evaluated. Among the root extracts, E4 and E5 showed remarkable radical scavenging activity. Among the leaf extracts, E10 and E11 showed promising radical scavenging activity. This is the first report of this kind, particularly the species collected from the Kingdom of Lesotho.

Additionally, the $\mathrm{IC}_{50}$ values of these extracts and fractions were also determined and the results are presented in Table 2. Extracts and fractions, E1-E12 showed $\mathrm{IC}_{50}$ values $<200,2469.87,344.86,<200,<200$, $623.33,2082.63,>3000,>3000,<200,292.80$ and $>3000$ $\mu \mathrm{g} / \mathrm{mL}$, respectively (Table 2 ). The positive control, ascorbic acid showed an $\mathrm{IC}_{50}$ value of $<200 \mu \mathrm{g} / \mathrm{mL}$ (Table 2). Extract E1 and fractions E4, E5 and E10 showed $\mathrm{IC}_{50}$ value of $<200 \mu \mathrm{g} / \mathrm{mL}$. Fractions E4 and E5 showed higher radical scavenging activity at all concentrations compared to positive control. The solvents viz. methanol, ethyl acetate and methanol/water might have higher extracting power of active ingrdients. These extracts or frations might have more active ingredients even at lower concentrations and therefore showed higher radical scavenging activity. They also showed a gradual increase in radical scavenging activity with increasing concentrations.

As stated previously that $S$. burchellii has not been studied previously. However, the antioxidant activity of other species from the Searsia genus has previously been reported. For example, various extracts from leaves and stem-bark of Searsia leptodictya and Searsia tripartita have been reported to have promising radical scavenging

Table 1. The percentage inhibition of DPPH radical scavenging activity of various extracts and fractions from roots and leaves of S. burchellii

\begin{tabular}{cccccccc}
\hline \multirow{2}{*}{ Extracts } & \multicolumn{7}{c}{ Concentrations $(\mu \mathrm{g} / \mathrm{mL}) / \%$ inhibition } \\
\cline { 2 - 8 } & 200 & 500 & 800 & 1000 & 1500 & 2000 & 3000 \\
\hline E1 & $49.40 \pm 4.54^{\mathrm{b}}$ & $54.98 \pm 4.47^{\mathrm{c}}$ & $55.86 \pm 3.92^{\mathrm{d}}$ & $56.48 \pm 4.17^{\mathrm{b}}$ & $57.13 \pm 3.81^{\mathrm{e}}$ & $57.68 \pm 3.35^{\mathrm{e}}$ & $58.00 \pm 3.31^{\mathrm{e}}$ \\
E2 & $6.60 \pm 4.50^{\mathrm{e}}$ & $18.93 \pm 2.14^{\mathrm{c}}$ & $27.23 \pm 1.64^{\mathrm{a}}$ & $33.53 \pm 4.52^{\mathrm{c}}$ & $43.51 \pm 1.61^{\mathrm{d}}$ & $47.89 \pm 2.07^{\mathrm{c}}$ & $50.86 \pm 1.56^{\mathrm{c}}$ \\
E3 & $30.19 \pm 2.53^{\mathrm{c}}$ & $56.69 \pm 2.26^{\mathrm{b}}$ & $61.70 \pm 1.70^{\mathrm{c}}$ & $62.00 \pm 1.57^{\mathrm{c}}$ & $62.31 \pm 1.16^{\mathrm{a}}$ & $62.70 \pm 1.26^{\mathrm{c}}$ & $63.27 \pm 1.93^{\mathrm{c}}$ \\
E4 & $57.56 \pm 4.23^{\mathrm{a}}$ & $59.45 \pm 3.27^{\mathrm{a}}$ & $60.32 \pm 2.45^{\mathrm{c}}$ & $61.24 \pm 2.47^{\mathrm{c}}$ & $61.89 \pm 2.28^{\mathrm{b}}$ & $62.45 \pm 2.24^{\mathrm{c}}$ & $63.11 \pm 1.77^{\mathrm{b}}$ \\
E5 & $55.00 \pm 0.60^{\mathrm{b}}$ & $57.99 \pm 1.05^{\mathrm{a}}$ & $59.55 \pm 0.44^{\mathrm{a}}$ & $60.32 \pm 1.03^{\mathrm{a}}$ & $61.40 \pm 0.84^{\mathrm{b}}$ & $62.56 \pm 0.58^{\mathrm{a}}$ & $63.14 \pm 0.84^{\mathrm{a}}$ \\
E6 & $45.43 \pm 2.64^{\mathrm{a}}$ & $49.22 \pm 2.06^{\mathrm{a}}$ & $51.74 \pm 2.28^{\mathrm{a}}$ & $53.41 \pm 2.50^{\mathrm{c}}$ & $54.35 \pm 2.92^{\mathrm{a}}$ & $55.52 \pm 1.96^{\mathrm{b}}$ & $56.59 \pm 1.48^{\mathrm{a}}$ \\
E7 & $9.74 \pm 3.96^{\mathrm{c}}$ & $22.60 \pm 3.41^{\mathrm{d}}$ & $25.24 \pm 3.88^{\mathrm{c}}$ & $31.68 \pm 1.96^{\mathrm{a}}$ & $46.73 \pm 1.42^{\mathrm{c}}$ & $55.61 \pm 2.69^{\mathrm{c}}$ & $58.48 \pm 0.90^{\mathrm{b}}$ \\
E8 & $6.00 \pm 1.92^{\mathrm{b}}$ & $6.89 \pm 2.01^{\mathrm{e}}$ & $7.91 \pm 2.49^{\mathrm{c}}$ & $8.65 \pm 2.69^{\mathrm{b}}$ & $9.86 \pm 1.53^{\mathrm{c}}$ & $10.44 \pm 2.09^{\mathrm{e}}$ & $11.63 \pm 2.90^{\mathrm{b}}$ \\
E9 & $3.32 \pm 0.95^{\mathrm{a}}$ & $6.45 \pm 1.50^{\mathrm{c}}$ & $8.09 \pm 3.35^{\mathrm{e}}$ & $11.25 \pm 4.01^{\mathrm{b}}$ & $18.05 \pm 2.06^{\mathrm{c}}$ & $22.69 \pm 0.65^{\mathrm{b}}$ & $25.92 \pm 2.96^{\mathrm{b}}$ \\
E10 & $34.17 \pm 4.10^{\mathrm{e}}$ & $59.24 \pm 0.68^{\mathrm{a}}$ & $61.61 \pm 0.18^{\mathrm{b}}$ & $63.39 \pm 0.35^{\mathrm{a}}$ & $63.98 \pm 0.36^{\mathrm{b}}$ & $64.49 \pm 0.12^{\mathrm{a}}$ & $64.91 \pm 0.15^{\mathrm{c}}$ \\
E11 & $40.34 \pm 6.41^{\mathrm{b}}$ & $50.87 \pm 6.54^{\mathrm{d}}$ & $56.93 \pm 4.66^{\mathrm{b}}$ & $60.97 \pm 0.82^{\mathrm{a}}$ & $63.69 \pm 1.20^{\mathrm{a}}$ & $64.37 \pm 1.26^{\mathrm{b}}$ & $64.88 \pm 1.48^{\mathrm{a}}$ \\
E12 & $17.27 \pm 6.29^{\mathrm{c}}$ & $25.00 \pm 4.16^{\mathrm{b}}$ & $27.42 \pm 2.20^{\mathrm{a}}$ & $28.72 \pm 2.43^{\mathrm{b}}$ & $29.30 \pm 2.35^{\mathrm{b}}$ & $30.27 \pm 2.74^{\mathrm{c}}$ & $32.32 \pm 2.90^{\mathrm{b}}$ \\
Ascorbic acid & $53.62 \pm 2.80^{\mathrm{a}}$ & $54.91 \pm 2.55^{\mathrm{a}}$ & $56.43 \pm 2.19^{\mathrm{a}}$ & $57.44 \pm 1.56^{\mathrm{c}}$ & $58.41 \pm 1.11^{\mathrm{a}}$ & $58.91 \pm 1.51^{\mathrm{a}}$ & $60.82 \pm 0.62^{\mathrm{b}}$ \\
\hline
\end{tabular}

Values with different superscript letters are significantly different within column. 
activity (El-Salam and Mohammed, 2015; Moteetee and Kose, 2017; Mtunzi et al., 2017). Phytochemicals such as phenols, tannins, saponins and flavonoids have been identified as active ingredients for this radical scavenging activity (El-Salam and Mohammed, 2015; Moteetee and Kose, 2017; Mtunzi et al., 2017). Free radicals and reactive oxygen species cause potentially harmful effects against the biological system, which include damaging DNA, proteins and lipids (Mon et al., 2011; Rodrigues et al., 2019). Fortunately, these harmful species can be scavenged and neutralised by natural secondary metabolites such as polyphenols, phenolic acids and flavonoids (Array et al., 2019; Rodrigues et al., 2019).

Table 2. The $\mathrm{IC}_{50}$ values of various extracts and fractions from roots and leaves of $S$. burchellii

\begin{tabular}{ccc}
\hline S/No. & Extracts/Fractions & $\mathrm{IC}_{50}$ in $\mu \mathrm{g} / \mathrm{mL}$ \\
\hline 1 & E1 & $<200$ \\
2 & E2 & 2469.87 \\
3 & E3 & 344.86 \\
4 & E4 & $<200$ \\
5 & E5 & $<200$ \\
6 & E6 & 623.33 \\
7 & E7 & 2082.63 \\
8 & E8 & $>3000$ \\
9 & E9 & $>3000$ \\
10 & E10 & $<200$ \\
11 & E11 & 292.8 \\
12 & E12 & $>3000$ \\
13 & Ascorbic Acid & $<200$ \\
\hline
\end{tabular}

\section{Conclusion}

Various extracts and their fractions from roots and leaves of $S$. burchellii were evaluated for their DPPH radical scavenging activity. The extracts from roots and their fractions showed radical scavenging activity ranging from $6.60 \pm 4.50$ to $63.27 \pm 1.93 \%$. The extracts from leaves and their fractions showed radical scavenging activity ranging from $3.32 \pm 0.95$ to $64.91 \pm 0.15 \%$. The $\mathrm{IC}_{50}$ values of these extracts and fractions were found to be $<200$ to $>3000 \mu \mathrm{g} / \mathrm{mL}$. Particularly, the methanolic crude extract from roots, ethyl acetate and methanol-water fractions from root extract and ethyl acetate fraction from leaf extract were identified as most potent with the $\mathrm{IC}_{50}$ values $<200 \mu \mathrm{g} /$ $\mathrm{mL}$. Based on the percentage inhibition of DPPH radical and $\mathrm{IC}_{50}$ value, the ethyl acetate fraction from leaf extract was identified as the most potent among all extracts or fractions. From this study, we concluded that extracts and their fractions from the roots and leaves of $S$. burchellii exhibited promising radical scavenging activity.

\section{Conflict of interests}

The authors declare no conflict of interest.

\section{Acknowledgments}

The authors thank the National University of Lesotho for its overall support. The authors also thank Mr Thelingoane Kobeli and Dr Lerato Lerato for their help in the collection and transportation of plant materials.

\section{References}

Array, E.J., Tonfack, D.F., Kingne, K.F., Kinge, E.E. and Womeni, H.M. (2019). Effect of different extraction solvents on the phenolic content and antioxidant activity of turmeric (Curcuma longa) from South-West Region, Cameroon. Food Research, 3(1), 86-90. https://doi.org/10.26656/ fr.2017.3(1).227

Compton, R.H. (1976). The Flora of Swaziland - Journal of South African Botany - Supplementary Volume No. 11, p. 1-484. Kirstenbosch, South Africa: National Botanic Gardens of South Africa.

Djakpo, O. and Yao, W. (2010). Rhus chinensis and Galla Chinensis-Folklore to modern evidence: Review. Phytotherapy Research, 24(12), 1739-1747. https://doi.org/10.1002/ptr.3215

El-Salam, A. and Mohammed, I. (2015). Phytoconstituents and the study of antioxidant, antimalarial and antimicrobial activities of Rhus tripartita growing in Egypt. Journal of Pharmacognosy and Phytochemistry, 4(2), 276-281.

Germishuizen, G. and Meyer, N.L. (2003). Plants of Southern Africa: An annotated checklist. Stelitzia, Naturalis, Leiden.

Matamane, P.R., Pillai, K.M., and Magama. S. (2020). DPPH radical scavenging activity of extracts from Urtica urens (Urticaceae). Journal of Medicinal Plants Research, 14(5), 232-238. https:// doi.org/10.5897/JMPR2019.6880

Moffett, R.O. (1994). Names of the Southern African species of Rhus (Anacardiaceae) and their etymology, Bothalia, 24(1), 67-76. https:// doi.org/10.4102/abc.v24i1.753

Moffet, R.O. (2007). Name changes in the old world Rhus and recognition of Searsia (Anacardiaceae). Bothalia, 37(2), 165-175. https://doi.org/10.4102/ abc.v37i2.311

Mokoroane, K.T., Pillai, M.K. and Magama, S. (2020). 2,2-diphenyl-1-picrylhydrazyl (DPPH) radical scavenging activity of extracts from Aloiampelos striatula. Food Research, 4(6), 2062-2066. https:// 
doi.org/10.26656/fr.2017.4(6).241

Mon, M.M., Maw, S.S. and Oo, Z.K. (2011). Quantitative determination of free radical scavenging activity and anti-tumor activity of some Myanmar herbal plants. International Journal of Pharmacology and Pharamaceutical Science, 5(3), 92-98.

Moteetee, A. and Kose, L.S. (2017). A review of medicinal plants used by the Basotho for treatment of skin Disorders: Their phytochemical, antimicrobial, and anti-inflammatory potential. African Journal of Traditional, Complementary, and Alternative medicine, 14(5), 121-137. https:// doi.org/10.21010/ajtcam.v14i5.16

Moteetee, A. and Van Wyk, B.E. (2011). The medicinal ethnobotany of Lesotho: a review. Bothalia, 41(1), 209-228. https://doi.org/10.4102/abc.v41i1.52

Moyo, M., Amoo, S.O., Ncube, B.M., Ndhlala, A.R., Finnie, J.F. and Van Staden, J. (2013). Phytochemical and antioxidant properties of unconventional leafy vegetables consumed in Southern Africa. South African Journal of Botany, 84, 65-71. https://doi.org/10.1016/j.sajb.2012.09.010

Mtunzi, F. M., Ejidike, P.I., Matamela, T., Dikio, E. and Klink, J.M. (2017). Phytochemical profiling, antioxidant and antibacterial activities of leaf extracts from Rhus leptodictya. International Journal of Pharmacognosy and Phytochemical Research, 9(8), 1090-1099. https://doi.org/10.25258/ phyto.v9i08.9616

Ndhlala, A.R., Aderogba, M.A., Ncube, B. and Van Staden, J. (2013). Antioxidative and cholinesterase inhibitory effects of leaf extracts and their isolated compounds from two closely related croton species. Molecules, 18(2), 1916-1932. https:// doi.org/10.3390/molecules 18021916

Nielsen, T.R.H., Kuete, V., Jager, A.K., Meyer, J.J.M. and Lall, N. (2012). Antimicrobial activity of selected South African medicinal plants. $B M C$ Complementary and Alternative Medicine, 12(74), 74-80. https://doi.org/10.1186/1472-6882-12-74

New Winger, H.D. (2000). African traditional medicine: A dictionary of the plant used and applications, $p$. 589. England: Medpharm Scientific

Palgrave, M.C. (2002). Palgrave's Trees of Southern Africa. $3^{\text {rd }}$ ed., Capetown: Struik Publishers.

Palmer, E. and Pitman, N. (1972). Trees of Southern Africa. Capetown and Amsterdam: Balkema.

Rodrigues, R.F.C., Lima, A., Melo. A.C.F.L. and Trindade, R.A. (2019). Physicochemical characterisation, bioactive compounds and in vitro antioxidant activities of commercial integral grape juices. International Food Research Journal, 26(2), 469-479.

Smith, C.A. (1966). Common names of South African plants. Memoirs of Botanical Survey of South Africa No. 35. Pretoria, South Africa: Government Printer.

Umberto, Q.F.L.S. (2012). Medicinal and Poisonous Plants. Nature. New York: CRC Press.

Van Wyk, B.E. and Van Wyk, P. (1997). Field guide to trees of Southern Africa. Capetown: Struik Publishers.

Van Wyk, B.E. and Cricke, N. (2000). People's Plants. Pretoria: Briza Publications. 